\title{
Precious metal enrichment in the Platreef, Bushveld Complex, South Africa: evidence from homogenized magmatic sulfide melt inclusions
}

\author{
D. A. Holwell • I. McDonald • I. B. Butler
}

Received: 14 April 2010/Accepted: 25 August 2010/Published online: 10 September 2010

(C) Springer-Verlag 2010

\begin{abstract}
Magmatic sulfide deposits are the most significant source of platinum-group elements (PGE) in the world. Key to understanding their genesis is determining the processes and timing of sulfide saturation, metal enrichment and crustal contamination. In this study, we have identified droplets of magmatic sulfide from the Platreef, South Africa, where droplets of sulfide have been trapped in the earliest crystallising phase, chromite. Due to their early entrapment at high temperatures, metal concentrations and ratios that they display are indicative of a very early-stage sulfide liquid in the system, as they will have cooled and fractionated within an essentially closed system, unlike interstitial blebs that crystallise in an open system as the magma cools. Analysis of these droplets in an
\end{abstract}

Communicated by C. Ballhaus.

D. A. Holwell ( $\square)$

Department of Geology,

University of Leicester, University Road,

Leicester LE1 7RH, UK

e-mail: dah29@le.ac.uk

I. McDonald

School of Earth and Ocean Sciences,

Cardiff University, Main Building,

Park Place, Cardiff CF10 3YE, UK

I. B. Butler

School of Geosciences,

The University of Edinburgh,

Grant Institute The King's Buildings,

West Mains Road, Edinburgh EH9 3JW, UK

I. B. Butler

ECOSSE (Edinburgh Collaborative of Subsurface Science and Engineering), A Joint Research Institute of the Edinburgh Research Partnership in Engineering and Mathematics, Edinburgh, UK opaque mineral like chromite by LA-ICP-MS is problematic as some of the fractionated inclusion is necessarily lost during cutting and polishing to initially identify the inclusion. This particularly affects the ability to representatively sample the most fractionated phases such as gold and platinum minerals. Here, using a novel technique whereby the inclusions are homogenized and quickly quenched, so that any cutting, polishing and subsequent LA-ICP-MS analysis samples a truly representative portion of the droplet. This has been used to show that early sulfide liquids in the Platreef were highly PGE-rich and had Pt/Pd ratios of close to unity that supports genetic models invoking sulfide saturation and metal enrichment prior to intrusion, with pre-enriched sulfides entrained within the Platreef magma.

Keywords Sulfide inclusions · Platinum-group elements . Laser-ablation ICP-MS · Platreef · Bushveld Complex

\section{Introduction}

The largest and most economically important resources of platinum-group elements (PGE) in the world are deposits associated with magmatic sulfides, whereby PGE are collected by immiscible sulfide liquids following the separation of a sulfide melt from a silicate magma. An extensive review of the formation and nature of magmatic sulfide deposits can be found in Naldrett (2004) and for PGE deposits in Maier (2005). The deposits include those with low volumes of sulfides in reef type settings within maficultramafic intrusions, such as the J-M Reef of the Stillwater Complex, Montana, USA; medium-volume sulfide deposits often in marginal or basal settings within similar intrusions (e.g. Platreef, Bushveld Complex, South Africa); and in 
high-volume sulfide deposits such as those in conduit settings (e.g. Noril'sk, Russia). For the latter two types of deposit, contamination from country rocks during emplacement has often had a controlling effect on the genesis of the sulfide mineralization, the volume of sulfide, the resultant mineralogy and/or the enrichment of PGE in the sulfide liquid. While it is possible to assess the role of external sulfur from contamination in the final sulfide product using sulfur isotopes (e.g. Ripley and Li 2003), it has so far not been possible to quantify the relative timing of any addition of sulfur and therefore its role as either a trigger for sulfide saturation or merely in an ore-modifying process (e.g. for the Platreef, Holwell et al. 2007). This is due to the open-system nature of the environment of fractionational crystallization of the sulfide liquids. The determination of sources of sulfur and precious metals in such deposits is fundamental in developing ore genesis models.

In this study, we have identified droplets of magmatic sulfide from one such deposit (the Platreef) that have been trapped in an early forming host mineral, chromite. As these have been trapped at a very early stage in the magmatic history and at high temperatures, the metal concentrations and isotopic ratios that they display are more likely to constrain the nature of the initial sulfide liquid in the magma. This is because they will have cooled and fractionated within an essentially closed system imposed by the host. Comparison of these inclusions with fractionated sulfide blebs formed from the crystallization of an interstitial, immiscible sulfide liquid, open to contamination and upgrading/dilution of precious metals and/or S during its cooling history can determine the triggering mechanism of sulfide saturation, the initial source of sulfur and precious metals and the relative timing of precious metal enrichment.

This paper details a novel approach to this problem whereby sulfide inclusions in an opaque mineral such as chromite are homogenized and quenched quickly before cutting, polishing and subsequent analysis by laser ablation-inductively coupled plasma-mass spectrometry (LAICP-MS). This potentially removes any bias caused by fractionation and subsequent partial sampling that analysis of unhomogenized or partially polished samples are subject to, so that an accurate assessment of the initial sulfide liquid in terms of metal contents and isotope ratios can be made. The wider implications of this technique are also discussed in terms of genetic and exploration models.

\section{The Platreef}

The Bushveld Complex in South Africa is the world's largest layered igneous intrusion, made up of a 7-8-km-thick sequence of mafic and ultramafic lithologies covering an area of $65,000 \mathrm{~km}^{2}$ (Eales and Cawthorn 1996). It is the largest repository of magmatic ore deposits on Earth and contains around $75 \%$ of the world's resources of platinumgroup elements in three main deposits: the UG2 chromitite, the Merensky Reef and the Platreef (Jollie 2009). The Platreef is a 10-to 400-m-thick unit of pyroxenitic lithologies with platinum-group element (PGE) and base metal sulfide (BMS) mineralization located in the northern limb of the Complex (Kinnaird and McDonald 2005). North from the town of Mokopane, the Platreef forms the base of the Bushveld layered igneous sequence and rests unconformably upon a succession of progressively older sedimentary units of the late Archean-early Proterozoic Transvaal Supergroup and Archean basement (Fig. 1). Northwards from Mokopane, these footwall units are comprised of quartzites and shales of the Timeball Hill Formation; shales of the Duitschland Formation; the Penge banded iron formation; the Malmani Subgroup dolomites; and, north from the farm Zwartfontein, Archean basement granites and gneisses, which form the footwall on the farm Overysel. The Platreef is overlain by norites and gabbronorites generally assigned to the Main Zone of the Complex (Fig. 1).

Mining of the Platreef by Anglo American since the mid 1990s plus a host of exploration by other companies has facilitated an expanding number of academic studies to be performed over the past decade. Many of these have been undertaken on Anglo Platinum's property between the farms Tweefontein and Overysel (Fig. 1), including studies of Platreef contamination, mineralization, structure, geochemistry, emplacement and mineralogy by Harris and Chaumba (2001), Armitage et al. (2002), McDonald et al. (2005), Holwell et al. (2005, 2006, 2007), and Holwell and McDonald (2006, 2007). Exploration along strike by other companies has also enabled the studies of the Platreef from drillcore in the area around Turfspruit and Macalacaskop by Kinnaird et al. (2005), Kinnaird (2005), Hutchinson and Kinnaird (2005), Sharman-Harris et al. (2005) and Hutchinson and McDonald (2008). In addition, Manyeruke et al. (2005) presented a paper detailing the characteristics of the Platreef from the farm Piet Potgietersrust Town and Townlands, around Mokopane. Many of these studies have shown that contamination has played a role in the development of Platreef mineralization (Manyeruke et al. 2005; Sharman-Harris et al. 2005), although Holwell et al. (2007) showed using $\mathrm{S}$ isotopes that contamination is likely to have been an ore-modifying, rather than an ore-triggering, process. Furthermore, McDonald and Holwell (2007) and McDonald et al. (2009) developed this to suggest that PGE enrichment occurred prior to intrusion, possibly in a staging chamber or conduit system, with PGE-rich sulfide being brought in with the Platreef magma during 


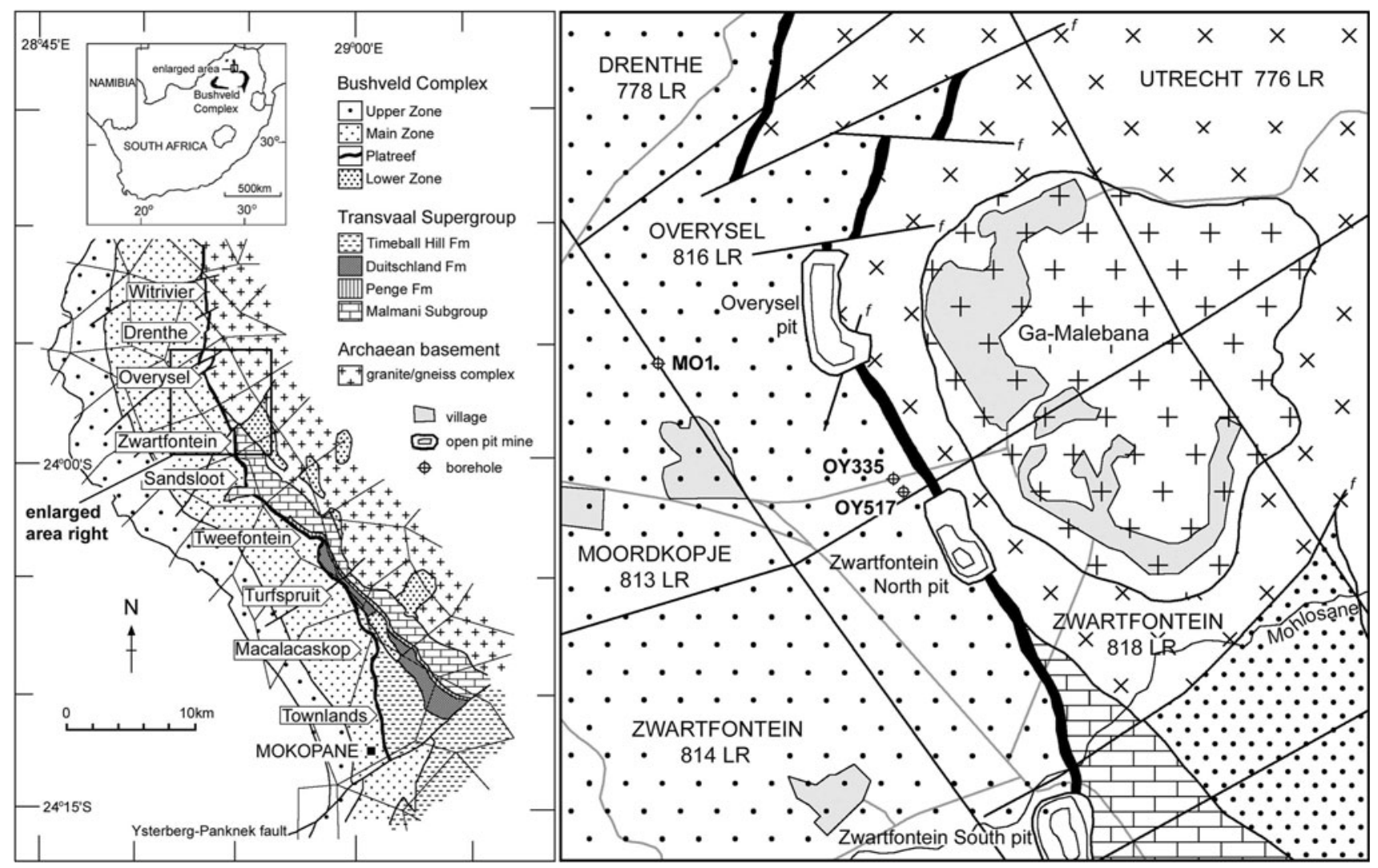

Fig. 1 Geological map of the southern part of the Northern Limb of the Bushveld Complex, showing the strike length of the Platreef and localities referred to in the text

emplacement. This study aims to test this model by identifying evidence of this pre-enriched sulfide liquid in sulfide melt inclusions.

\section{The significance of sulfide melt inclusions}

The study of silicate melt inclusions is well developed for applications looking into compositions of early-stage melts in magmatic and mantle systems (e.g. Kamenetsky 1996; Danyushevsky et al. 2000, 2001; Spandler et al. 2000, 2005). The homogenization of these inclusions by heating and subsequent quenching produces glasses with compositions likely to represent that of the trapped melt. The study of sulfide inclusions is less common, and less well developed, with only a few examples of a similar homogenization technique (Sparks and Mavrogenes 2005; McNeill et al. 2008). In the same way that trapped silicate melt inclusions can reveal the composition of parental silicate magmas, so too can sulfide inclusions reveal the parental compositions of sulfide melts within magmatic systems.

The mechanisms of sulfide saturation involved in producing sulfide liquids and economic sulfide deposits include the addition of external sulfur from country rocks (e.g. Ripley et al. 2003), contamination by silica due to the assimilation of felsic country rocks (e.g. Li and Naldrett 1993) and an increase in magma oxygen fugacity, for example, in response to the assimilation of oxygen-bearing country rocks (Buchanan and Nolan 1979). As a variety of contamination-related processes are capable of inducing $\mathrm{S}$ saturation, basal and marginal sulfide mineralization is a common feature of many layered intrusions such as Noril'sk, the Duluth Complex, Voisey's Bay (Ripley and Li 2003) and the Uitkomst Complex (Li et al. 2002).

It is in these marginal settings that the genesis of these deposits is most contentious. While contamination is often invoked as the causative mechanism for the sulfide saturation, it is also possible that the sulfide is magmatic in origin, and any contamination-related effects are merely secondary or upgrade the sulfur content. Recent $\mathrm{S}$ isotope work has suggested that the Platreef is an example of this latter situation (Holwell et al. 2007). The use of sulfur isotopes can be used to determine the origin of the sulfur in the sulfides, providing the contaminant has a $\delta^{34} \mathrm{~S}$ signature significantly different to primary, normal mantle-derived $\mathrm{S}$ associated with mafic and ultramafic magmatic rocks $\left(\delta^{34} \mathrm{~S} 0 \pm 2 \%\right.$, Omhoto and Rye Ohmoto and Rye 1979). 
This method reveals whether any external sulfide has had a role in the genesis of the final sulfide product. However, as the crystallization of the sulfide takes place in an open system where immiscible sulfide droplets can interact with the interstitial silicate magma during crystallization, this contamination could take place at any time after emplacement, and it becomes impossible to determine the relative timing of that contamination. Therefore, it is not necessarily possible to distinguish between an initially magmatic sulfide subsequently contaminated and one that formed initially due to the addition of external sulfide.

The exception to this is if there are inclusions of sulfide in early forming minerals such as chromite or olivine. In addition to determining the initial source of sulfur in such inclusions, the precious metal contents of these will also reveal whether the initial sulfide liquid was relatively enriched or depleted in these metals compared to the final sulfide product. This is because as trapped droplets, any fractionation will occur within the droplet, with little or no ability for any fractionated liquid or fluid-rich phase to migrate away, as is possible with the interstitial droplets. Conversely, no further enrichment of precious metals by scavenging from the silicate magma or $\mathrm{S}$ upgrading from contamination with a S-bearing country rock can occur for the same reason. Therefore, metal ratios, metal abundances and isotope ratios in these early trapped liquid droplets can provide evidence of the composition of early-stage mineralizing sulfide which is fundamental in testing genetic models. For example, a higher PGE tenor in the initial sulfide would imply dissolution during crystallization of the sulfide liquid (i.e. PGE enrichment must have occurred prior to emplacement, and sulfur is added during emplacement of the magma, possibly via contamination), whereas a lower PGE content in the initial sulfide would imply that PGE enrichment occurred in situ, with the main sulfide liquidscavenging PGE from the silicate magma during cooling and subsequent crystallization of a PGE-rich sulfide. In addition, as $\mathrm{Re}$ and $\mathrm{Os}$ are chalcophile and would be preferentially retained in the sulfide, the droplets would retain Os isotope ratios indicative of the initial sulfide liquid, rather than any contamination associated with the interstitial melt. This could be used to resolve the origin of the precious metals in terms of mantle versus crustal components in a more robust manner than could be achieved using bulk sulfides.

The identification of trapped inclusions of sulfide within early forming minerals and their subsequent analysis is therefore hugely important in distinguishing the source of both the sulfide and the metals within it. The ability to do this has fundamental implications not just for genetic models for individual deposits but for strategies employed in the exploration of marginal PGE deposits.

\section{Samples and methods}

In this study, we have identified droplets of sulfide within very early crystallising chromite in the Platreef, Bushveld Complex, South Africa (Fig. 1). This pilot study utilizes samples taken from borehole core drilled on the farm Overysel by Anglo Platinum. Samples are taken from boreholes OY335 and OY517, drilled close to the surface outcrop of the Platreef in the southeast corner of the farm, and from a down-dip portion of the Platreef sampled at depth in borehole MO1, drilled on the boundary between Overysel and the adjacent farm Moordkopje (Fig. 1).

The petrology and mineralogy of the Platreef at Overysel has been described in detail by Cawthorn et al. (1985) and by Holwell and McDonald (2006). Details of the platinum-group mineralogy are given in Holwell and McDonald (2007). The Platreef at Overysel is made up of medium- to coarse-grained feldspathic pyroxenites, containing $>75 \%$ cumulus orthopyroxene, with intercumulus plagioclase and a little clinopyroxene, with accessory base metal sulfides and chromite. Quartz becomes more common as an accessory phase within the interstitial assemblage as the footwall contact is approached. The samples used in this study from the OY335 and OY517 boreholes are from close to the base of the Platreef succession in a 5-m-thick unit of feldspathic pyroxenite with disseminated chromite. A 2-m-thick chromite-free feldspathic pyroxenites separate this unit from the banded gneisses of the Archean basement. The rocks contain around $70 \%$ cumulus orthopyroxene, which range in texture from fine- to medium-grain size, $15 \%$ intercumulus plagioclase, heavily altered by sericitisation and saussuritization, and $10 \%$ intercumulus clinopyroxene. The remainder of the assemblage is made up of minor quartz, chromite, phlogopite and base metal sulfides. In the MO1 core, chromite occurs as a pocket of chromite-rich coarse-grained feldspathic pyroxenites, grading into chromitite in places, present in the central part of a thick (>300 m) Platreef succession.

The samples contain around 1-20\% chromite, most commonly present in the interstitial areas along with plagioclase, sometimes as clusters of several grains or as polygrain aggregates (Fig. 2). Some grains are, however, present as inclusions within the cumulus orthopyroxene grains (Fig. 2). The chromite grains are euhedral and range in size from $0.1 \mathrm{~mm}$ up to around $0.5 \mathrm{~mm}$ and are clearly the earliest formed phase in the crystallization history. Compositionally, the chromites contain around $42 \mathrm{wt} \%$ $\mathrm{Cr}_{2} \mathrm{O}_{3}$ and are relatively high in $\mathrm{Fe}$ - and Ti-rich, containing around $43 \mathrm{wt} \% \quad \mathrm{FeO}$ and $2 \mathrm{wt} \% \quad \mathrm{TiO}_{2}$ (Holwell and McDonald 2006). Yudovskaya and Kinnaird (2010) presented data for chromite along the whole strike length of the Platreef between Macalacaskop and Overysel, and these compositions are consistent with their large dataset. 


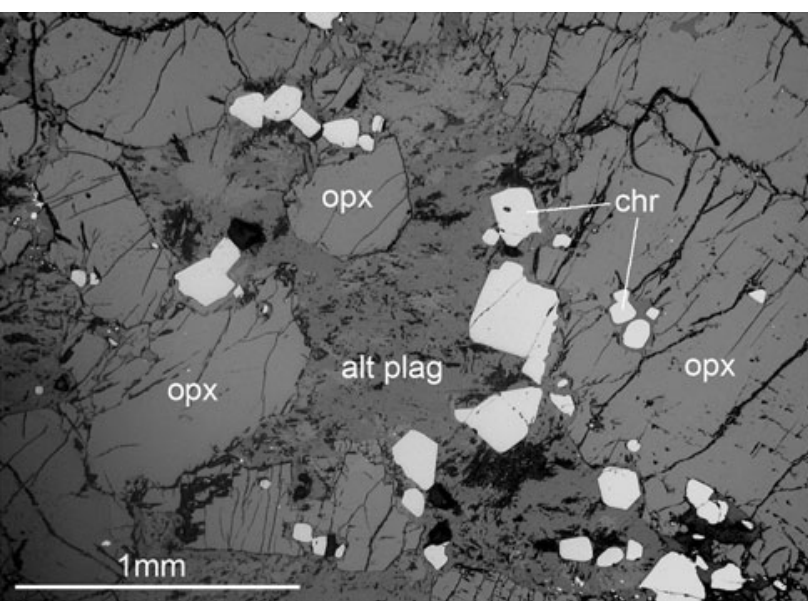

Fig. 2 Reflected light photograph of the chromitiferous quartzofeldspathic pyroxenite made up of cumulus chromite (chr) and variably sized cumulus orthopyroxene (opx) with interstitial altered plagioclase (alt plag)

Laser-ablation ICP-MS on sulfide inclusions was carried out using a New Wave Research UP213 UV laser system coupled to a Thermo X Series ICP-MS at Cardiff University. Ablations were carried out under He (flow rate $\sim 0.7$ $\mathrm{L} / \mathrm{min}$ ) and the resulting vapor combined with Ar (flow rate $0.56-0.65 \mathrm{~L} / \mathrm{min}$ ) before delivery to the ICP-MS. Most analyses were performed using a $30-\mu \mathrm{m}$ laser spot. The isotopes ${ }^{33} \mathrm{~S},{ }^{59} \mathrm{Co},{ }^{61} \mathrm{Ni},{ }^{65} \mathrm{Cu},{ }^{66} \mathrm{Zn}$ and ${ }^{68} \mathrm{Zn}$ were detected to monitor the composition of the sulfides, and in the case of $\mathrm{Zn}$, the presence of chromite, together with the precious metal isotopes ${ }^{99} \mathrm{Ru},{ }^{101} \mathrm{Ru},{ }^{103} \mathrm{Rh},{ }^{105} \mathrm{Pd},{ }^{106} \mathrm{Pd},{ }^{189} \mathrm{Os}$, ${ }^{193} \mathrm{Ir},{ }^{195} \mathrm{Pt}$ and ${ }^{197} \mathrm{Au}$. The isotopes of the semi-metals ${ }^{75} \mathrm{As},{ }^{82} \mathrm{Se},{ }^{125} \mathrm{Te},{ }^{121} \mathrm{Sb}$ and ${ }^{209} \mathrm{Bi}$ were also analyzed as these elements commonly form PGM. The acquisitions typically lasted $60 \mathrm{~s}$, consisting of $45 \mathrm{~s}$ of measurement of the gas blank followed by 15 ablation which, due to the small size of the inclusions, was enough time to completely vaporise the target. Sulfur was determined by internal standard corrections using ${ }^{33} \mathrm{~S}$ and $\mathrm{S}$ determined by SEM on homogenized and unhomogenized sulfides. Major elements were also analyzed in homogenized inclusions by area analysis using SEM-EDA techniques. Full details of the LA-ICP-MS analytical conditions and standards are described in McDonald (2005) and Holwell and McDonald (2007), and examples of the technique applied to interstitial
Platreef sulfide blebs are described in Holwell and McDonald (2007) and Hutchinson and McDonald (2008). The PGE-bearing pyrrhotite standard Po724, distributed by Memorial University (Sylvester et al. 2005), was analyzed as an external certified reference material at the beginning and the end of an analytical run to check the calibration achieved using the Cardiff sulfide standards (which include known quantities of all the metals and semi-metals listed in the data Table 2). Identical spot analyses to those used for the sulfide inclusions were performed using of Po724 as an unknown and are compared with the certified values in Table 1. All elements shown in Table 2 are quantitative, following calibration with the standards mentioned above.

\section{Unhomogenized inclusions}

\section{Mineralogy}

Sulfide inclusions are visible in around $2 \%$ of the chromite grains in section, although in three dimensions, presumably a larger overall percentage of the grains hold inclusions. The inclusions display negative crystal shapes imposed by the crystal structure of the host chromite, commonly producing inclusions with a hexagonal morphology that were almost always in the size range 10-30 $\mu \mathrm{m}$ across, with exceptions up to $100 \mu \mathrm{m}$ (Fig. 3). Similar trapped sulfide inclusions have been described from chromites in the Andriamena region of Madagascar by Ohnenstetter et al. (1999) and McDonald et al. (1999).

The timing of capture of the sulfide droplets by the host mineral is fundamentally important if trying to relate the composition of the inclusions themselves to any parental sulfide liquid. The solidus temperature for chromite is very high, being in the region of $1,200-1,400^{\circ} \mathrm{C}$, depending on oxygen fugacity and pressure (Roeder and Reynolds 1991). The morphology of the included sulfide droplets (Fig. 3) implies that when the inclusions were trapped by the crystallising chromite, they remained liquid as the chromite crystallized, thus inheriting their morphology from the chromite, which would be expected as a sulfide liquid will not begin to crystallise until around $1,000^{\circ} \mathrm{C}$. Thus, the sulfide inclusions within the chromite represent droplets of sulfide liquid present within the magma at temperatures of

Table 1 Concentrations of PGE and semi-metals in Memorial University standard Po724

\begin{tabular}{llllllllllll}
\hline Sample & $\mathrm{As}$ & $\mathrm{Sb}$ & $\mathrm{Te}$ & $\mathrm{Bi}$ & $\mathrm{Ru}$ & $\mathrm{Rh}$ & $\mathrm{Pd}$ & $\mathrm{Os}$ & $\mathrm{Ir}$ & $\mathrm{Pt}$ & $\mathrm{Au}$ \\
\hline & $\mathrm{ppm}$ & $\mathrm{ppm}$ & $\mathrm{ppm}$ & $\mathrm{ppm}$ & $\mathrm{ppm}$ & $\mathrm{ppm}$ & $\mathrm{ppm}$ & $\mathrm{ppm}$ & $\mathrm{ppm}$ & $\mathrm{ppm}$ & $\mathrm{ppm}$ \\
Mem Po724-1 & $<6$ & $<1$ & $<0.7$ & $<0.2$ & 40.0 & 34.5 & 44.3 & 34.1 & 34.2 & 34.8 & 44.4 \\
Mem Po724-2 & $<6$ & $<1$ & 0.9 & $<0.2$ & 38.9 & 35.8 & 44.1 & 35.8 & 35.1 & 36.5 & 45.2 \\
Certified values & $\mathrm{n} / \mathrm{a}$ & $\mathrm{n} / \mathrm{a}$ & $\mathrm{n} / \mathrm{a}$ & $\mathrm{n} / \mathrm{a}$ & $37.0 \pm 1.0$ & $37.0 \pm 1.7$ & $45.0 \pm 0.8$ & $35.2 \pm 1.9$ & $36.2 \pm 0.5$ & $35.9 \pm 0.7$ & $47.3 \pm 2.4$ \\
\hline
\end{tabular}


Table 2 Absolute concentrations of 16 unhomogenized and 15 homogenized sulfide inclusions from chromite hosts within the Platreef on Overysel/Moordkopje

\begin{tabular}{|c|c|c|c|c|c|c|c|c|c|c|c|c|c|}
\hline Sample & $\mathrm{Ni}$ wt $\%$ & $\mathrm{Cu}$ wt $\%$ & As ppm & $\mathrm{Sb}$ ppm & Te ppm & $\mathrm{Bi}$ ppm & $\mathrm{Ru}$ ppm & Rh ppm & Pd ppm & Os ppm & Ir ppm & Pt ppm & $\mathrm{Au}$ ppm \\
\hline \multicolumn{14}{|c|}{ Unhomogenized } \\
\hline 303rsoi1 & 15.05 & 3.47 & 25 & $<1$ & 4.4 & 8.4 & 15.6 & 26.3 & 154.3 & 0.7 & 5.7 & 234.4 & 2.0 \\
\hline 303r soi3 & 14.46 & 24.80 & 78 & $<1$ & 2.4 & 12.0 & 23.8 & 32.6 & 165.5 & 0.8 & 4.1 & 169.8 & 0.1 \\
\hline 303r ukn2 & 9.52 & 4.44 & 10 & $<1$ & 7.7 & 32.1 & 40.6 & 43.3 & 48.5 & 1.3 & 18.9 & 183.9 & 1.4 \\
\hline $303 r$ soi4 & 27.75 & 2.84 & $<6$ & $<1$ & $<0.7$ & 4.3 & 8.9 & 38.2 & 194.8 & 0.3 & 2.1 & 69.3 & 0.0 \\
\hline 303r soi5 & 4.81 & 19.94 & 11 & 1.1 & 0.7 & 0.8 & 2.6 & 82.2 & 286.1 & 0.4 & 1.9 & 70.8 & 0.1 \\
\hline 303r soi6 s & 3.53 & 21.43 & $<6$ & $<1$ & $<0.7$ & 0.6 & 10.3 & 21.9 & 130.5 & 0.2 & 0.5 & 15.2 & 0.0 \\
\hline 303r soi6d & 17.55 & 1.15 & 11 & $<1$ & 4.2 & 91.1 & 65.7 & 92.0 & 101.9 & 5.6 & 25.4 & 577.1 & 1.2 \\
\hline 303 r soi8 s & 8.29 & 2.51 & $<6$ & 7.6 & $<0.7$ & 1.3 & 9.5 & 10.4 & 122.4 & 0.7 & 5.3 & 83.2 & 0.0 \\
\hline 303r soi8d & 22.27 & 2.57 & 7 & $<1$ & 47.3 & 143.7 & 33.1 & 50.2 & 365.4 & 2.2 & 13.7 & 357.1 & 1.2 \\
\hline 303r soi9 & 20.83 & 11.05 & 6 & $<1$ & 55.6 & 157.9 & 37.0 & 52.2 & 317.4 & 5.2 & 23.4 & 545.7 & 0.1 \\
\hline $303 \mathrm{pb}-1$ & 10.51 & 13.74 & $<6$ & $<1$ & 41.8 & 122 & 28.2 & 33.6 & 90.7 & 2.56 & 6.32 & 471 & 4.36 \\
\hline $303 \mathrm{pb}-3$ & 9.70 & 9.20 & $<6$ & $<1$ & $<0.7$ & 138 & 228 & 38 & 190 & 16.69 & 16.9 & 333 & 0.01 \\
\hline $303 \mathrm{pb}-4$ & 6.48 & 20.99 & $<6$ & 9.46 & 189 & 274 & 156 & 150 & 354 & 11.13 & 76.4 & 2,072 & 8.85 \\
\hline 303-pb6a & 2.08 & 14.99 & $<6$ & $<1$ & 16.3 & 66.0 & 8.23 & 61.4 & 103 & 1.71 & 30.0 & 823 & 0.87 \\
\hline 303-pb6b & 15.80 & 2.51 & $<6$ & $<1$ & 67.4 & 6.62 & 19.0 & 39.5 & 61.6 & 4.37 & 24.3 & 754 & 5.98 \\
\hline 303soi7 & 3.92 & 38.89 & 17 & $<1$ & 42.3 & 140.2 & 37.8 & 50.8 & 280.6 & 3.0 & 12.1 & 317.8 & 0.1 \\
\hline Average & 12.0 & 12.2 & 20.6 & 6.1 & 39.9 & 74.9 & 45.3 & 51.4 & 185.4 & 3.6 & 16.7 & 442.3 & 1.6 \\
\hline \multicolumn{14}{|l|}{ Homogenized } \\
\hline Incl A1-1a & 21.31 & 8.72 & $<6$ & $<1$ & 8.2 & 170 & 9.4 & 8.8 & 166 & 1.0 & 1.6 & 35.3 & 3.4 \\
\hline Incl A1-1b & 11.57 & 19.05 & 184 & 16.4 & 31.7 & 80.5 & 25.5 & 21.3 & 115 & 0.4 & 4.1 & 41.9 & 0.8 \\
\hline Incl A1-3 & 2.84 & 27.40 & $<6$ & $<1$ & 17.2 & 129 & 37.5 & 42.6 & 433 & 1.8 & 12.2 & 321 & 40.3 \\
\hline Incl A1-4 & 27.29 & 10.40 & $<6$ & $<1$ & 14.0 & 147 & 27.6 & 34.9 & 102 & 2.4 & 6.5 & 243 & 5.5 \\
\hline Incl A1-5 & 7.95 & 3.53 & $<6$ & 38.1 & $<0.7$ & 11.9 & 22.8 & 7.4 & 37.5 & 1.5 & 4.6 & 83.8 & 0.4 \\
\hline Incl A1-5a(i) & 26.99 & 2.86 & 49 & $<1$ & $<0.7$ & 85.4 & 44.0 & 60.8 & 131 & 2.4 & 13.3 & 218 & 2.4 \\
\hline Incl A1-5a(ii) & 16.89 & 9.69 & 157 & 21.3 & 26.0 & 108 & 104 & 138 & 274 & 10.7 & 23.6 & 585 & 2.8 \\
\hline Incl A1-6b & 13.33 & 19.31 & 48 & $<1$ & $<0.7$ & 728 & 14.4 & 17.8 & 84.7 & 1.1 & 5.3 & 114 & 4.3 \\
\hline Incl A2-2 & 1.99 & 21.16 & $<6$ & 1.9 & 15.9 & 220 & 18.9 & 10.6 & 70.5 & 1.3 & 3.3 & 71.4 & 3.1 \\
\hline Incl A2-3a & 8.97 & 1.70 & 16 & 2.6 & 1.0 & 14.8 & 10.8 & 5.8 & 37.4 & 0.3 & 1.2 & 24.6 & 1.3 \\
\hline Incl A2-1 & 24.86 & 6.24 & 74 & 4.0 & 1.5 & 85.7 & 40.0 & 39.4 & 122 & 1.0 & 10.4 & 75.9 & 5.4 \\
\hline Incl B1-1 & 3.64 & 33.52 & $<6$ & 5.8 & 19.5 & 954 & 171 & 151 & 683 & 13.4 & 38.8 & 903 & 15.8 \\
\hline Incl D1-1 & 1.17 & 13.17 & $<6$ & $<1$ & 6.9 & 27.7 & 5.5 & 8.4 & 53.7 & 0.4 & 0.8 & 36.2 & 3.4 \\
\hline Incl A1-2 & 1.51 & 22.69 & $<6$ & $<1$ & 6.9 & 94.6 & 3.5 & 3.8 & 49.1 & 1.1 & 0.9 & 50.1 & 0.9 \\
\hline Incl A2-3b & 14.35 & 11.35 & $<6$ & $<1$ & 10.7 & 347 & 11.7 & 9.7 & 48.7 & 0.8 & 2.4 & 49.1 & 2.9 \\
\hline Average & 12.3 & 14.1 & 88.0 & 12.9 & 13.3 & 213.6 & 36.4 & 37.4 & 160.5 & 2.6 & 8.6 & 190.2 & 6.2 \\
\hline Sample & $\begin{array}{l}\mathrm{Ni} \\
\mathrm{ppm}\end{array}$ & $\begin{array}{l}\mathrm{Cu} \\
\mathrm{ppm}\end{array}$ & $\begin{array}{l}\text { As } \\
\text { ppm }\end{array}$ & $\begin{array}{l}\mathrm{Sb} \\
\mathrm{ppm}\end{array}$ & $\begin{array}{l}\text { Te } \\
\text { ppm }\end{array}$ & $\begin{array}{l}\mathrm{Bi} \\
\mathrm{ppm}\end{array}$ & $\begin{array}{l}\mathrm{Ru} \\
\mathrm{ppb}\end{array}$ & $\begin{array}{l}\mathrm{Rh} \\
\mathrm{ppb}\end{array}$ & $\begin{array}{l}\mathrm{Pd} \\
\mathrm{ppb}\end{array}$ & $\begin{array}{l}\text { Os } \\
\text { ppb }\end{array}$ & $\begin{array}{l}\mathrm{Ir} \\
\mathrm{ppb}\end{array}$ & $\begin{array}{l}\mathrm{Pt} \\
\mathrm{ppb}\end{array}$ & $\begin{array}{l}\mathrm{Au} \\
\mathrm{ppb}\end{array}$ \\
\hline \multicolumn{14}{|c|}{ Bulk rock (note units) } \\
\hline OY335-303 & 559.6 & 120.9 & - & - & - & - & 0.5 & 1.8 & 155 & - & 0.4 & 106.9 & 18.9 \\
\hline Sample & $\begin{array}{l}\mathrm{Ni} \\
\mathrm{wt} \%\end{array}$ & $\begin{array}{l}\mathrm{Cu} \\
\mathrm{wt} \%\end{array}$ & $\begin{array}{l}\text { As } \\
\text { ppm }\end{array}$ & $\begin{array}{l}\mathrm{Sb} \\
\mathrm{ppm}\end{array}$ & $\begin{array}{l}\text { Te } \\
\text { ppm }\end{array}$ & $\begin{array}{l}\mathrm{Bi} \\
\text { ppm }\end{array}$ & $\begin{array}{l}\mathrm{Ru} \\
\mathrm{ppm}\end{array}$ & $\begin{array}{l}\mathrm{Rh} \\
\mathrm{ppm}\end{array}$ & $\begin{array}{l}\mathrm{Pd} \\
\mathrm{ppm}\end{array}$ & $\begin{array}{l}\text { Os } \\
\text { ppm }\end{array}$ & $\begin{array}{l}\text { Ir } \\
\text { ppm }\end{array}$ & $\begin{array}{l}\mathrm{Pt} \\
\mathrm{ppm}\end{array}$ & $\begin{array}{l}\mathrm{Au} \\
\mathrm{ppm}\end{array}$ \\
\hline \multicolumn{14}{|c|}{ Platreef PGE Tenors } \\
\hline $100 \%$ sulfide & - & - & - & - & - & - & 32.0 & 39.8 & 271 & - & 9.7 & 192 & 6.2 \\
\hline
\end{tabular}

Samples are from borehole OY335 (unhomogenized) and OY335 and OY517 (homogenized). Variations in absolute concentration between inclusions are in part related to the size of the inclusion. Bulk rock data and tenors (average Platreef bulk rock recalculated to 100\% sulfide) from Holwell and McDonald (2007) 

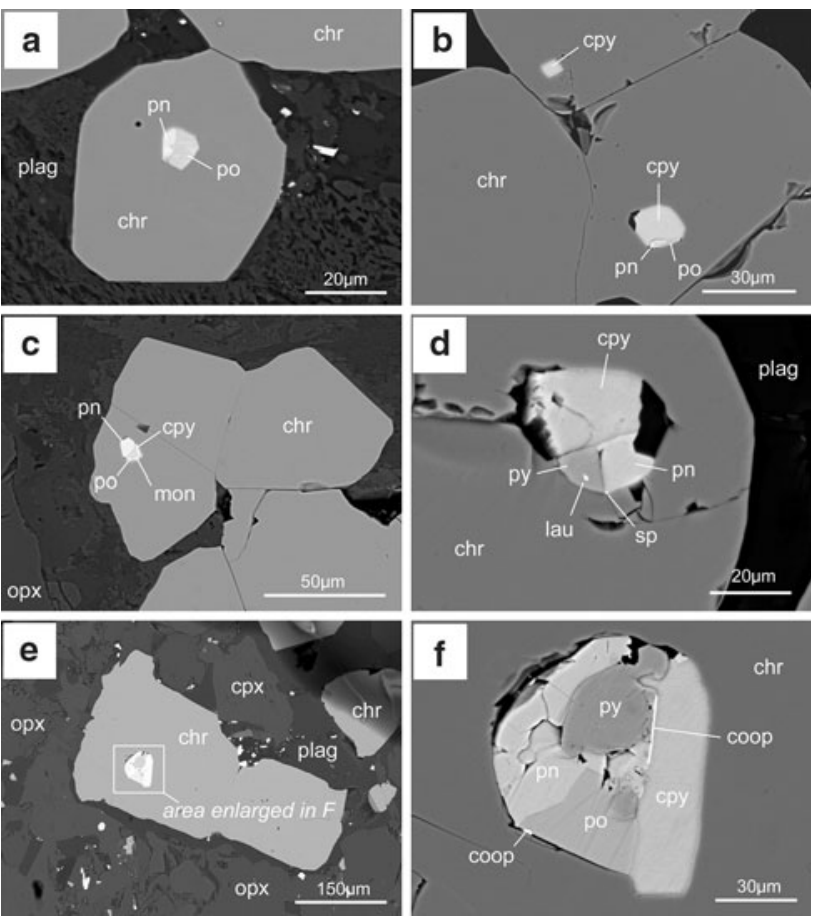

Fig. 3 Backscattered electron photomicrographs of sulfide inclusions within chromite. a hexagonal inclusion of pyrrhotite (po) and pentlandite (pn) within chromite (chr), surrounded by altered plagioclase (plag). b hexagonal inclusion of chalcopyrite, pentlandite and pyrrhotite and a small inclusion of chalcopyrite. c polyphase inclusion made up of chalcopyrite, pyrrhotite, pentlandite and a small micron-sized grain of the PGM moncheite (mon). d polyphase inclusion made up of chalcopyrite, pentlandite, pyrite (py) and the PGMs laurite (lau) and sperrylite (sp). e large inclusion set within chromite, enlarged in $\mathbf{f}$. $\mathbf{f}$ inclusion composed of pentlandite, pyrrhotite, pyrite, chalcopyrite and two grains of cooperite (coop)

at least $1,200^{\circ} \mathrm{C}$, during the crystallization of the earliest solidus phase, chromite.

The sulfide inclusions are commonly polyphase, fractionated blebs containing a typically magmatic assemblage of pyrrhotite, pentlandite and chalcopyrite, with many also containing pyrite coexisting with pyrrhotite (Fig. 3d, f). Some inclusions that only appeared to be composed of a single phase (e.g. Fig. 3b) may have contained other phases that were not exposed on the polished surface. However, in many cases (such as that in Fig. 3b), small chalcopyritedominated inclusions were often observed close to larger, $\mathrm{Ni}-\mathrm{Fe}$ dominated inclusions. Conversely, some fractionated phases within the inclusion must have been polished away, and therefore the two-dimensional appearance of a single inclusion is unlikely to represent its true modal mineralogy. Nevertheless, the majority of the smaller single-phase inclusions, often present as 'satellite' inclusions around larger polyphase inclusions, were dominated by chalcopyrite. Some platinum-group minerals (PGM), including cooperite $(\mathrm{PtS})$, laurite $\left(\mathrm{RuS}_{2}\right)$, moncheite $\left(\mathrm{PtTe}_{2}\right)$ and sperrylite $\left(\mathrm{PtAs}_{2}\right)$, were present in some inclusions and were generally present at the margins of the bleb or at sulfide grain boundaries within the inclusion (Fig. 3c, d, f).

\section{LA-ICP-MS of unhomogenized inclusions}

A series of spot analyses on 16 unhomogenized inclusions located in cut and polished sections of chromite from the Platreef were performed. Spot analyses were performed in order to ablate as much inclusion material as possible. A laser spot size of $30 \mu \mathrm{m}$ was found to be sufficient to ensure the total ablation of the majority of the inclusions. Larger inclusions $(>40 \mu \mathrm{m})$ were ablated using a laser spot size of $55 \mu \mathrm{m}$. Due to the distinctly different compositions between sulfide and chromite, it was possible to resolve and isolate portions of the laser time spectra contributed by sulfide and chromite for signal processing. In all the analyses, $\mathrm{Cu}, \mathrm{Ni}$ and all of the PGE were detected in varying amounts. In addition, most, but not all inclusions, had some detectable $\mathrm{Au}$ and semi-metals. Figures $4 \mathrm{a}-\mathrm{d}$ show examples of time-resolved analysis (TRA) spectra from the laser ablation of three separate sulfide inclusions, which are typical of the patterns from all the analyses we undertook. Each laser ablation analysis is shown on two separate diagrams, with $\mathrm{Cu}, \mathrm{Pd}, \mathrm{Pt}, \mathrm{Au}$, and the semimetals shown on the first, and $\mathrm{Ni}, \mathrm{Rh}$ and the IPGE shown on the second. S and Zn (effectively monitors of inclusion/ chromite material, respectively) are depicted on both diagrams in each pair.

Figures $4 a$ and $b$ show the TRA spectra of a relatively small inclusion, showing peaks in most elements in the first few seconds after the laser is switched on (at $43 \mathrm{~s}$ ). $\mathrm{Cu}$ shows a slightly delayed peak to $\mathrm{Ni}$, and this is likely to be a function of the relative proportions of chalcopyrite and pentlandite sampled by the laser as the pit was ablated. Pt, $\mathrm{Pd}$ and the semi-metals show a good correlation with each other, though not necessarily with $\mathrm{Cu}$. The IPGE and Rh show a good correlation with each other and with $\mathrm{Ni}$, as would be expected if these elements partitioned into pentlandite. The readings of the elements present within the inclusion then drop away dramatically due to the laser ablating the entire inclusion in a very short period of time due to their small size, and the plateau attained by the $\mathrm{Zn}$ signal indicates total ablation of the inclusion. In addition, the amount of material released from a spot ablation decreases with penetrated depth, and spot analyses usually display patterns with a sharp peak followed by a gradual decrease.

The TRA spectra in Fig. $4 \mathrm{c}$ and $\mathrm{d}$ show a distinctive arched pattern over a period of around $10 \mathrm{~s}$. The arch shape is caused by the diameter of the inclusion increasing and then decreasing with depth, such that the original exposed surface revealed only the tip of the inclusion. 

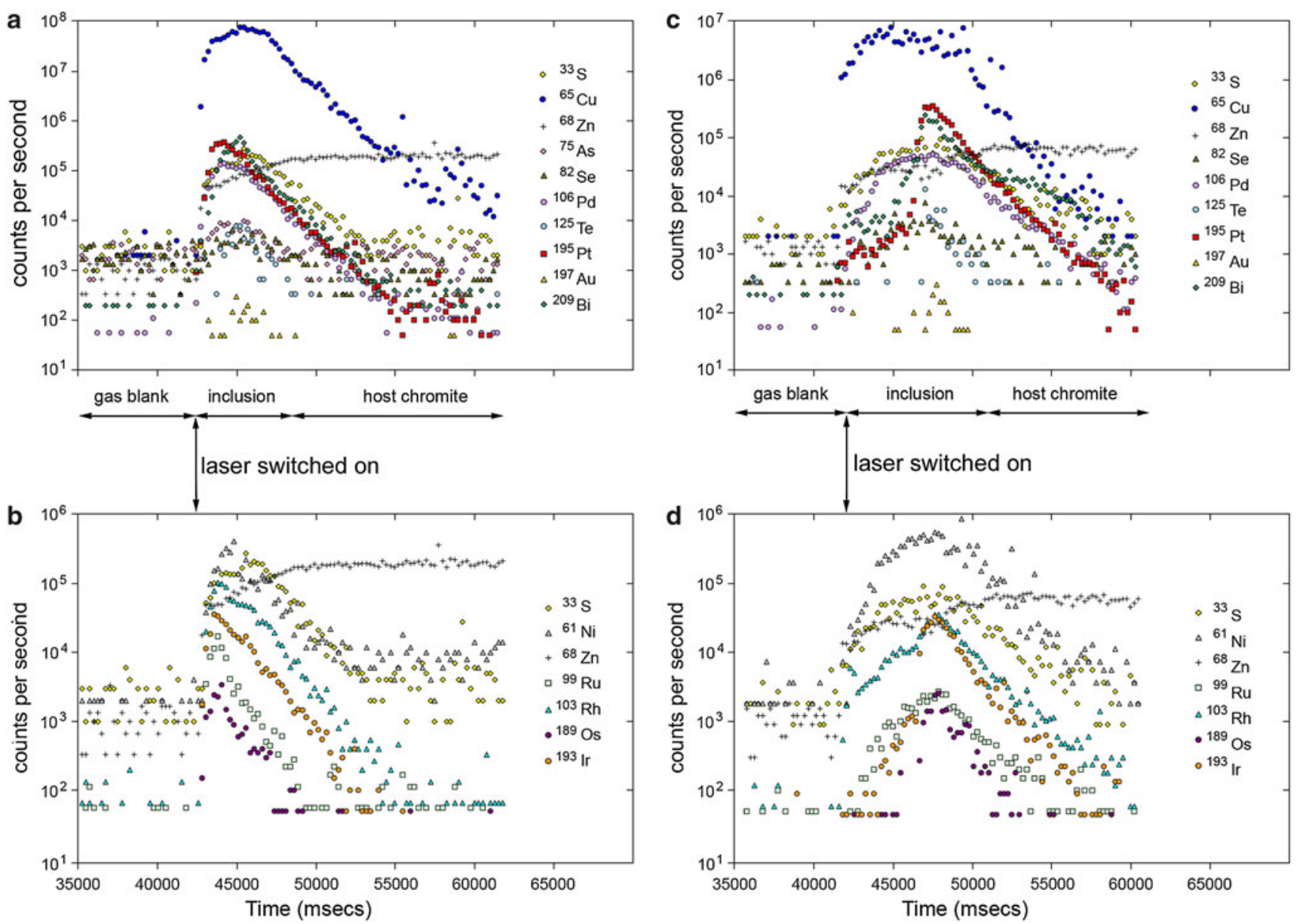

Fig. 4 Two pairs of split time-resolved analysis (TRA) spectra from the ablation of unhomogenized sulfide inclusions within chromite grains. $\mathbf{a}$ and $\mathbf{b}$ small inclusion. $\mathbf{c}$ and $\mathbf{d}$ larger inclusion

In comparison with that represented in Figs. $4 a$ and $b$, this is a much larger inclusion. Internally, the composition is heterogeneous showing clear internal fractionation of the droplet, especially with regard to the PGE. Pd and the IPGE tend to mirror the $\mathrm{Ni}$ and $\mathrm{S}$ signals, and Pt seems to be controlled by $\mathrm{Bi}$ and $\mathrm{Te}$, suggestive of its presence as Pt-Bi-Te PGM, rather than in solid solution within the sulfides. $\mathrm{Cu}$ and $\mathrm{Ni}$ again give different peaks, and $\mathrm{Cu}$ gives a slight ' $\mathrm{M}$ '-shaped profile. This can be explained when combined with the $\mathrm{Ni}$ signal to indicate that the initial ablation sampled relatively more chalcopyrite, then more pentlandite, then more chalcopyrite again at the end, which would be consistent with chalcopyrite forming the rim of the inclusion.

Occasionally, two inclusions were sampled, usually a smaller, $\mathrm{Cu}$-dominant one (e.g. Fig. 3b) and a larger, Niand $\mathrm{Cu}$-rich inclusions. In these occurrences, the second ablation was completely coincidental as this was not visible beneath the surface of the opaque mineral. The TRA spectra patterns shown in the larger inclusions are similar to that in Fig. 4c and d, with Pd, Rh and the IPGE roughly following $\mathrm{S}$ and $\mathrm{Ni}$, whereas $\mathrm{Pt}$ has a distinct peak associated with $\mathrm{Te}$ and $\mathrm{Bi}$. Copper again has a separate peak to $\mathrm{Ni}$. In the smaller, $\mathrm{Cu}$-dominant inclusions, $\mathrm{Ni}$ was comparatively low, and not all the PGE were present. It is unclear whether this is due to only partial sampling or whether the smaller inclusion was of a different composition.

The sulfide inclusions studied by Sparks and Mavrogenes (2005) could be observed microscopically below the surface of their garnet hosts and analyzed without exposing the inclusion. Chromite is an opaque mineral, and in order to avoid resorting to random laser sampling, inclusions must be exposed by polishing. The relationships identified in the TRA spectra clearly show the fractionated nature of the inclusions, and this poses a problem in terms of calculating a bulk composition for each inclusion. Obviously, ablating roughly spherical inclusions that have been exposed in the surface of a polished block will not sample $100 \%$ of the original inclusion, as some must be lost in the polishing process to expose the inclusion in the first place. Because there is obvious internal fractionation within the 

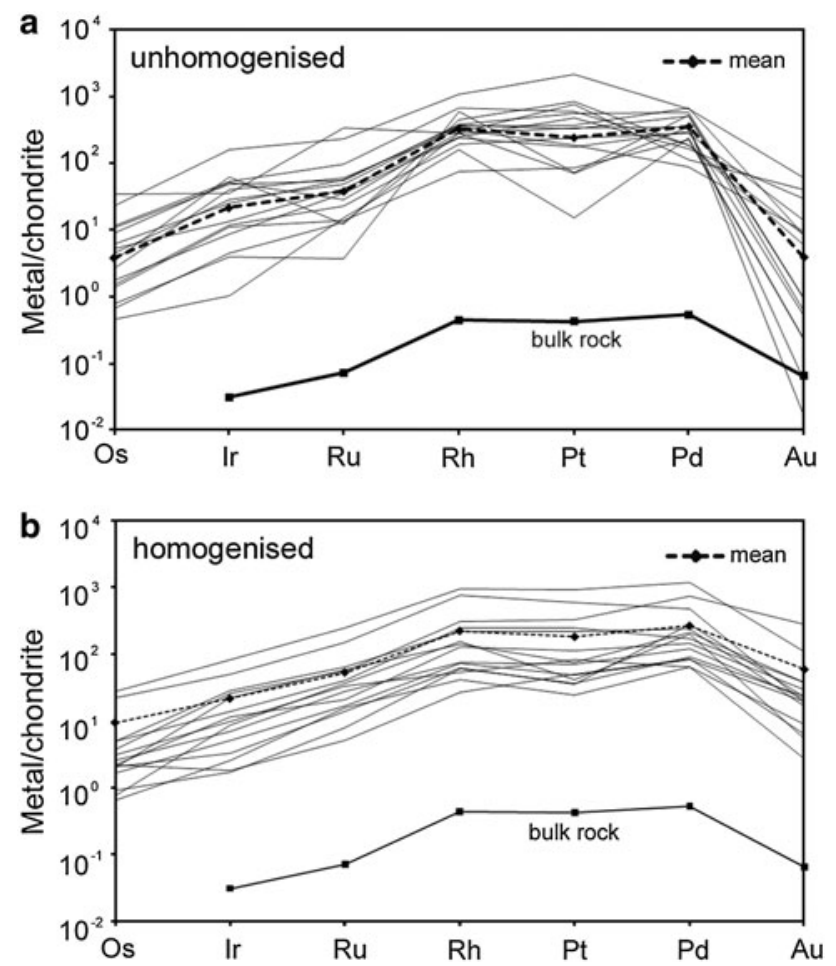

Fig. 5 Chondrite-normalized diagram showing PGE profiles for a all unhomogenized inclusions, their mean and the bulk rock values, and b for homogenized inclusions, their mean and the bulk rock

inclusions as revealed by the TRA spectra and the SEM analyses, none of the individual ablations will accurately represent the bulk composition, as some fractionated phases may have been polished away. A possible exception is the case shown where a second inclusion is ablated beneath the surface; however, even here there is no way of telling if all the inclusion was ablated. This first-order sampling problem in opaque phases is likely to particularly affect the most fractionated phases present around the margins of the inclusions (most likely $\mathrm{Pt}, \mathrm{Pd}, \mathrm{Au}$ and semi-metal bearing phases, e.g. Helmy et al. (2006)).

The actual compositions of the inclusions (or more specifically the parts thereof that were ablated) are shown in Table 1 and on a chondrite normalized diagram in Fig. 5a. Actual abundances are extremely high although variable between individual analyses. In part, differences in bulk composition can be attributed to the size of the inclusion with the high concentrations equating to large inclusions, as some host material will always be ablated in each analysis, and thus the relative amount of ablated material that was composed of sulfide material is greater in cases of larger inclusions, but using the same laser spot size. There are also differences in relative abundance of elements within each inclusion. In particular, $\mathrm{Pt}$ and $\mathrm{Au}$ are particularly variable. It is likely that these variations and anomalies are caused by the fractionation and subsequent polishing and sampling effect. In an attempt to reduce this, we have averaged the compositions from all the individual analyses, with the rationale being that over the range of analyses, an average will be more closely representative of bulk inclusion composition. Figure 5 also shows the average of the inclusion compositions, together with the average bulk rock PGE composition for the samples containing the inclusions. These bulk rock values are also shown in Table 2. The averaged inclusion and bulk rock profiles are similar, indicating that this may better represent a true composition of the sulfide inclusions, although gold is still relatively much lower in the inclusions. There are problems with this approach, however, as there is the possibility that different inclusions may have different compositions to begin with and also that the whole-rock analysis that is used as a comparison includes interstitial sulfides within the pyroxenites in addition to any inclusions within the chromite grains.

\section{Homogenized inclusions}

In order to overcome the problems clearly posed by the loss of fractionated material during polishing and/or sampling in opaque minerals such as chromite, we attempted to homogenize the sulfide inclusions by heating the samples to a temperature of $1,195^{\circ} \mathrm{C}$, which would be sufficient to melt the sulfides (which should melt below $1,000^{\circ} \mathrm{C}$, e.g. Barnes et al. 2006), but not the surrounding chromite material that should be stable at temperatures below $1,200^{\circ} \mathrm{C}$ (Roeder and Reynolds 1991), before quenching quickly to produce homogenized inclusions. Importantly, the sample was then cut and polished after this process to expose multiple inclusions that had been homogenized as complete droplets beneath the surface of the sample. This approach is summarized schematically in Fig. 6. This novel approach produces inclusions that are completely homogenized, and the effects of polishing and incomplete ablation are minimized, with any LA-ICP-MS analysis of a cut homogenized inclusion in principle being representative of the initial composition of the included droplet as a whole.

\section{Details of method}

Homogenization experiments were performed at $1,195^{\circ} \mathrm{C}$ in a vertical tube, 1 atmosphere gas mixing furnace and quenched rapidly to room temperature by dropping into water. Samples of chromite-bearing pyroxenite were cut into $1 \times 1 \times 0.5 \mathrm{~cm}$ blocks, held in a Pt wire cage and suspended from a drop-quench apparatus using a fine 0.1$\mathrm{mm} \mathrm{Pt}$ wire. Samples were introduced to the cold zone of the $\mathrm{CO}_{2}$-flushed furnace tube. $\mathrm{H}_{2}$ gas was added to the $\mathrm{CO}_{2}$ 
Fig. 6 Schematic

representation of the problem with polishing and subsequent sampling of (a and

b) fractionated material in an opaque phase and (c and $\mathbf{d})$ the solution by homogenizing the inclusions
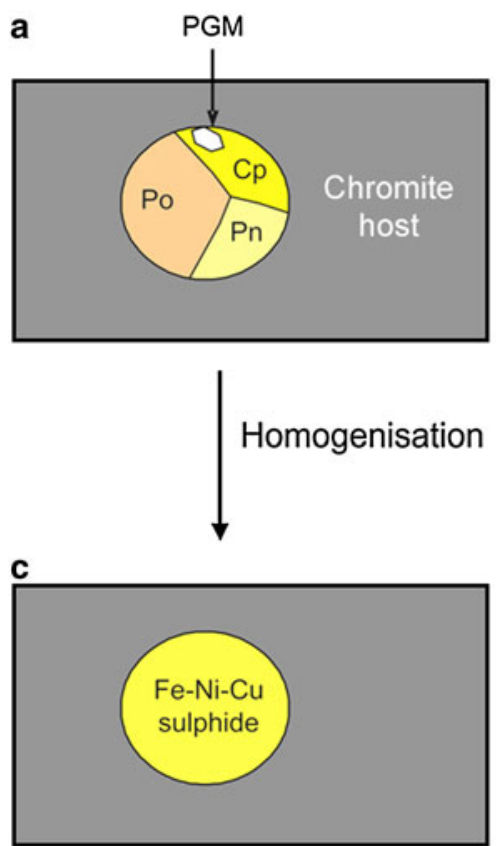

b

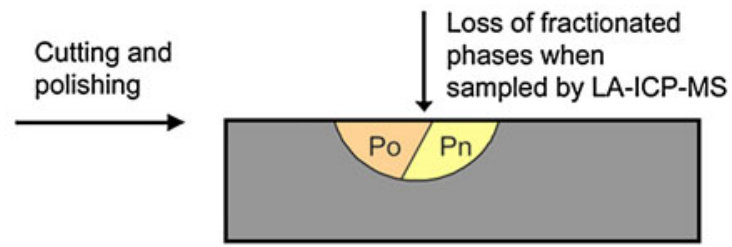

d

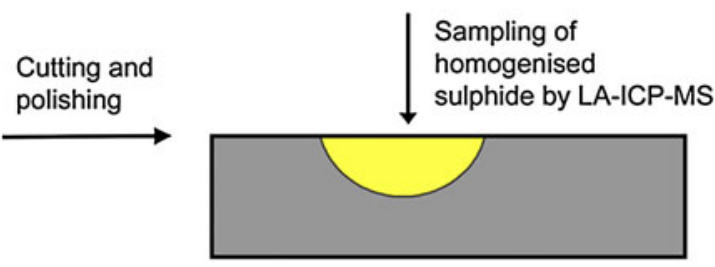

stream by means of a precision gas proportioner to generate an $\mathrm{fO}_{2}$ close to QFM-1 at the hot-spot temperature (Deines et al. 1974) to prevent oxidation of the inclusions as well as the bulk sample. The samples were then lowered into the furnace hot-spot and held at temperature for 90-100 min. The homogenization temperature was monitored using an R-type thermocouple positioned close to the sample in the furnace. Samples were quenched rapidly by electrically fusing the $0.1-\mathrm{mm} \mathrm{Pt}$ wire that permitted the sample to drop directly into a cold water trap attached to the furnace tube.

There are a number of advantages of this approach over the homogenization technique used by Sparks and Mavrogenes (2005), which used a 1/2 piston cylinder. Primarily, relatively large block samples can be homogenized, potentially providing tens to hundreds of melt inclusions that can be exposed by successive polishing steps. In addition, the quench rate that can be achieved with our technique means that a large number of samples can be processed fairly quickly with modest preparation.

\section{Mineralogy of homogenized inclusions}

The textures of the homogenized inclusions are shown in Fig. 7a-d. The inclusions have kept their shape as would be expected if the chromite host was unaffected by the heating. Cracks across the chromite grains in Figs. 7a and $\mathrm{c}$ are from the subsequent cutting and polishing following quenching, and there is no evidence of draining of sulfide material through any cracks in the chromite host. Typically, a very fine-grained myrmekitic or cell exsolution texture is observed, which is characteristic of rapidly
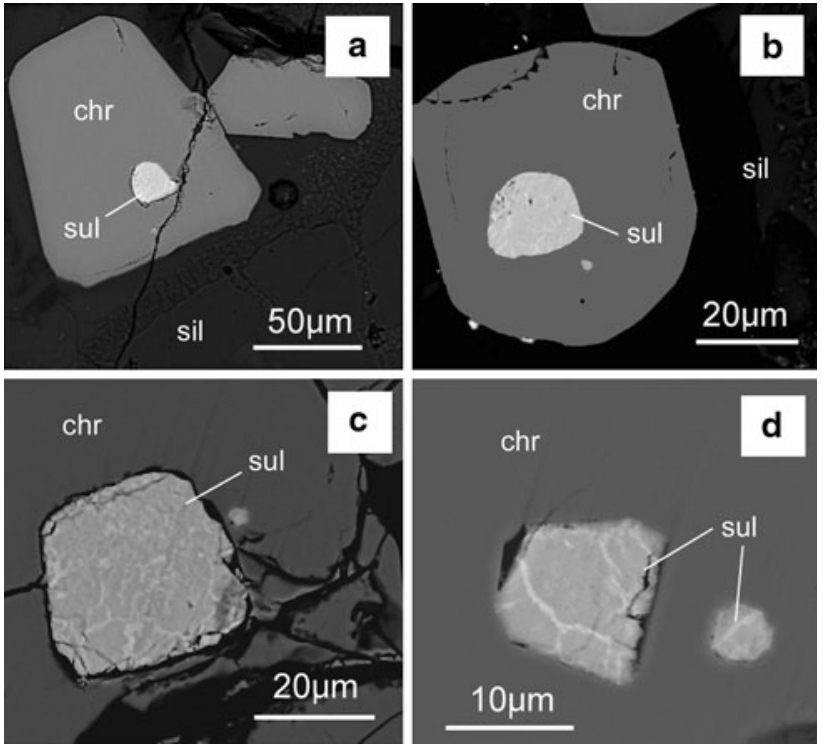

Fig. 7 Mineralogy of a number of homogenized sulfide (sul) inclusions within chromite (chr), showing myrmekitic and cell exsolution textures. Note the myrmekitic melt texture of the silicates (sil) in a

quenched sulfide melts (Sparks and Mavrogenes 2005; McNeill et al. 2008).

\section{LA-ICP-MS of homogenized inclusions}

Figure $8 \mathrm{a}$ and $\mathrm{b}$ shows a split TRA spectra for one of the homogenized inclusions, typical of all analyses performed on this material. The most striking feature of these profiles is the extremely smooth patterns present for all elements, 


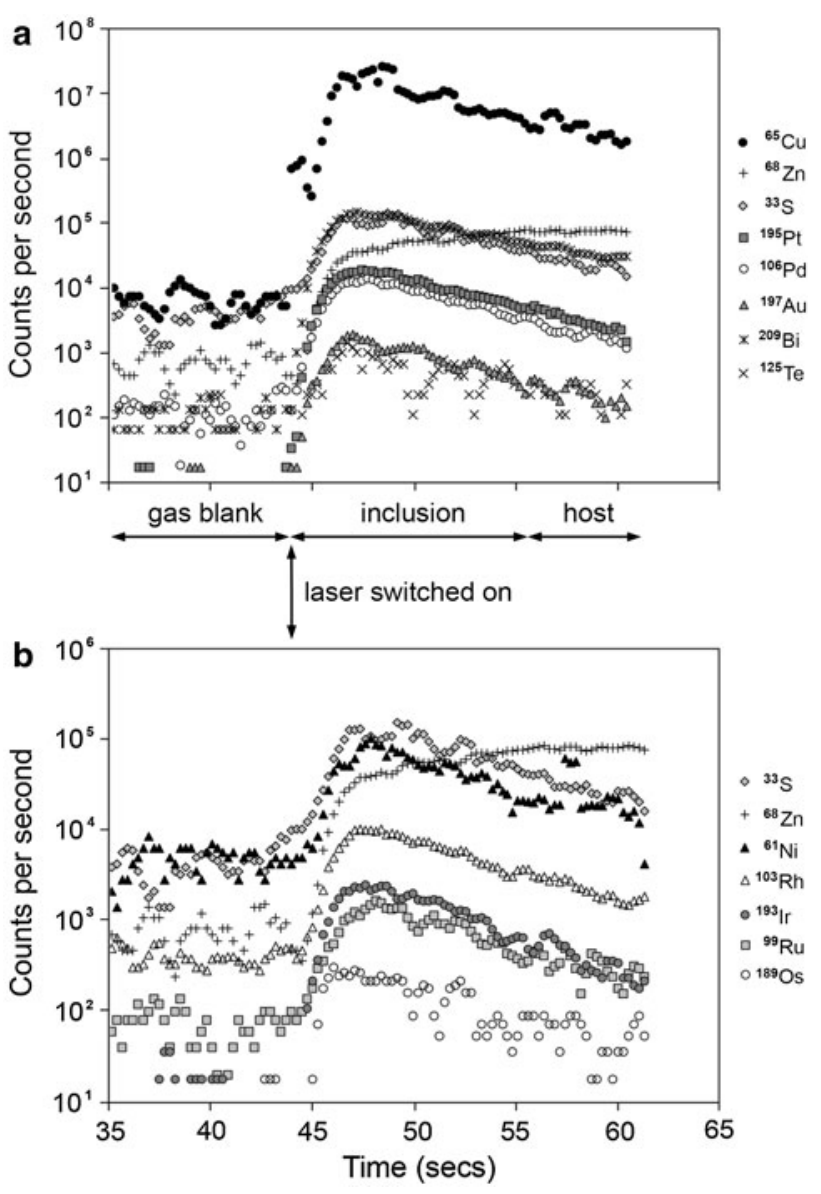

Fig. 8 A pair of split time-resolved analysis (TRA) spectra from the ablation of a homogenized sulfide inclusion within chromite

which mirror each other, showing that the ablated material is truly homogenized. For example, $\mathrm{Cu}$ and $\mathrm{Ni}$ form correlatory patterns (c.f. Fig. 4), as do all the PGE. All the PGE, semi-metals and gold, an element often not present in the unhomogenized analyses, were present in all ablations of the homogenized inclusions and showed similar smooth correlatory patterns.

Absolute concentration of $\mathrm{Ni}, \mathrm{Cu}, \mathrm{PGE}, \mathrm{Au}$ and the semi-metals $\mathrm{Bi}$ and $\mathrm{Te}$ in the homogenized inclusions is shown in Table 2 Average concentrations of precious metals in the homogenized inclusions are $2.6 \mathrm{ppm}$ Os, $8.6 \mathrm{ppm} \mathrm{Ir}, 36.5 \mathrm{ppm} \mathrm{Ru}, 30.7 \mathrm{ppm} \mathrm{Rh}, 190 \mathrm{ppm} \mathrm{Pt}$, $161 \mathrm{ppm} \mathrm{Pd}$ and $6.2 \mathrm{ppm} \mathrm{Au}$. These concentrations are remarkably similar to those calculated for bulk PGE in $100 \%$ sulfide by Holwell and McDonald (2007), which is also shown in Table 2. On a chondrite-normalized plot (Fig. 5b), the range in profile shape is much reduced compared with those of the unhomogenized inclusions (Fig. 5a), and each pattern mimics that of the bulk rock sample. This, in the case of gold that always showed a distinct deficit in ablations of unhomogenized inclusions, clearly shows the robust nature of this technique in sampling representative material from any single inclusion.

A curious relationship noted within these analyses is that although the PGE ratios and subsequent chondrite-normalized profiles are consistent, $\mathrm{Cu}$ and $\mathrm{Ni}$ ratios vary considerably from one inclusion to the next (Table 2). This shows that each droplet does not actually have a consistent composition in terms of major elements. The reasons for this are discussed below.

\section{Discussion}

Origin of the sulfide inclusions

Experimental data in the $\mathrm{Fe}-\mathrm{Ni}-\mathrm{Cu}-\mathrm{S}$ system have been used to explore the partitioning behavior of PGE during the crystallization of monosulfide solid solution (mss) from a sulfide liquid (e.g. Fleet et al. 1993; Li et al. 1996; Barnes et al. 1997; Ballhaus et al. 2001; Mungall et al. 2005). The results of these studies have found that in S-rich, alloy-poor systems (applicable to the Platreef), the IPGE and Rh partition into mss, which then cools and recrystallises to pyrrhotite and pentlandite, with these elements remaining in solid solution. Studies on natural samples have confirmed this behavior (e.g. Ballhaus and Sylvester 2000; Barnes et al. 2006; Holwell and McDonald 2007). According to the experiments, Pt, Pd and Au will partition into the residual liquid after mss crystallization. However, rather than these elements partitioning into iss and then, with falling temperature, chalcopyrite, it seems that they are concentrated in a late stage, immiscible semi-metal-rich melt (Helmy et al. 2006; Holwell and McDonald 2010). This is consistent with natural associations between Pt and Pd tellurides and bismuthotellurides concentrated around the margins of sulfide grains (e.g. Cabri and Laflamme 1976; Prichard et al. 2004; Barnes et al. 2006; Holwell and McDonald 2007). Thus, in the sulfide inclusions trapped within chromite we have studied, one would expect a fractionated droplet of IPGE-rich pyrrhotite, IPGE-rich pentlandite, chalcopyrite and a range of Pt- and Pd-semimetal PGM plus gold. It is likely that the PGM and the chalcopyrite would be located toward the palaeo-top, or more generally, the margins of the inclusion, but importantly, with no expulsion or loss of any late-stage PGE/ semi-metal-rich fluid to the surrounding silicate material (Prichard et al. 2004).

In general, this is exactly what is observed in our analyses of the unhomogenized inclusions, with a consistent sulfide mineralogy of pyrrhotite, euhedral pentlandite and chalcopyrite, and even some small PGM visible (Fig. 4). The IPGE have a good correlation with $\mathrm{S}$ and $\mathrm{Ni}$, indicating their presence in solid solution within sulfide, 
and $\mathrm{Pt}$ appears to be controlled by $\mathrm{Bi}$, indicating its presence as discreet PGM. Chalcopyrite is generally more concentrated toward the margins, as expected, although there is no way of ascertaining any palaeo-orientation of the grains (as in Prichard et al. 2004), due to the likely turbulent nature of the magmatic system during cooling as crystallization of the surrounding silicate liquid. Curiously, many of the inclusions also contain pyrite coexisting with the other sulfide phases, which is not necessarily what is expected. It is possible for pyrite to exsolve from S-rich pyrrhotite, but this would only produce around $10 \%$ pyrite (A. J. Naldrett, pers. comm, 2007), whereas in our inclusions pyrite is, on average, present in similar proportions to pyrrhotite. What is more likely is that the pyrite is an alteration product from pyrrhotite which has lost $\mathrm{Fe}$ to chromite. In this case, the loss of Fe from sulfide to surrounding chromite would produce excess sulfur (Naldrett and Lehmann 1987). Due to the trapped nature of the inclusions, this excess sulfur cannot be lost and so causes mineralogical changes instead, with pyrrhotite converted to pyrite.

The common occurrence of small, apparently chalcopyrite dominant 'satellite' inclusions close to larger inclusions (e.g. Fig. 3b) initially appears to be from the simple sampling bias as already described; however, our data show that some of the homogenized inclusions are $\mathrm{Cu}$ rich and others Ni-rich, which would not be expected if these are true representations of a homogenous sulfide liquid. This may be due to the trapping of two separate sulfide liquids, i.e. from a sulfide that has already fractionated. What is perhaps more likely, and the interpretation we favor, is that the occurrence of small, Cu-rich inclusions very close to larger more $\mathrm{Ni}$ - and $\mathrm{Fe}$-rich ones can be explained as being the result of small droplets of the $\mathrm{Cu}$-rich liquid (iss), formed during the crystallization of mss at around $1,000^{\circ} \mathrm{C}$, that became separated and squeezed out as the chromite underwent lattice reorganisation during cooling. Therefore, in some cases where this has occurred, major element data need to be treated with caution. This interpretation still implies that the initial trapping took place at magmatic temperatures of a fully liquid sulfide.

The analyses of the droplets clearly show that this early sulfide was enriched in PGE. The fractionated nature of the droplets, allied with the cutting and sampling problem means that even averaged, the results of the ablation of unhomogenized inclusions will never be totally representative of the initial composition of that sulfide droplet. The technique of homogenizing the sulfide droplets allows the accurate analysis of these inclusions to high precision, with a high degree of confidence. While the homogenization and quenching has produced sulfides with some fine-grained exsolution textures (Fig. 7), these fine-scale variations are too fine-grained to have a significant effect on the subsequent LA-ICP-MS analysis. The robustness of the technique is seen in the smoothing of profiles in both Figs. 5 and 8 and in particular by the difference in Au content. The discrepancy in the Au content between homogenized and unhomogenized inclusions is interpreted to be an extreme case of the nugget effect affecting how representative the analyses are. Clearly there must be gold in the inclusions, although most of the unhomogenized ones have very little, suggesting that Au was preferentially lost in the cutting and polishing process, which would imply that it is concentrated on the margins of the droplets.

There also remains the possibility that diffusion of elements may occur after initial crystallization. Spandler et al. (2007) showed that rare earth elements can diffuse from silicate melt inclusions into host olivine and chromite and that this REE diffusion is sufficiently rapid to counter the effects of low partition coefficients. This allows a significant flux of REEs through the olivine and chromite and thus Spandler et al. (2007) challenged the accepted view that trapped melt inclusions truly represented the initial composition of a trapped melt. The inclusions we have studied differ fundamentally from those of the aforementioned work in that they are sulfide, rather than silicate inclusions. Partitioning of the PGE into sulfide is so strong, it is unlikely that diffusion of PGE into chromite would be significant or even occur at all, and therefore the concentrations of PGE seen in sulfide melt inclusions are likely to represent true parental compositions.

\section{Implications for genesis of Platreef mineralization}

In this study, we have identified droplets of PGE- and semimetal-rich sulfide within very early crystallising chromite at the base of the Platreef sequence on Overysel. This has implications for assessing the initial composition of the Platreef sulfide, as due to their presence as trapped droplets, any fractionation will occur within the droplet, with little or no ability for any fractionated liquid or fluid-rich phase to migrate away, as is possible with the interstitial blebs. In addition, the droplets should be isolated from any further upgrading of PGE, or dissolution of sulfide, as modelled by Kerr and Leitch (2005). Therefore, metal ratios and abundances in these early trapped liquid droplets can provide evidence of the composition of the initial mineralizing Platreef sulfide that is fundamental in testing models for Platreef genesis.

The results of the ablation of the homogenized inclusions reveal that they are very PGE-rich. They are almost identical to the bulk composition, recalculated to $100 \%$ sulfide of the interstitial sulfides of the Platreef calculated by Holwell and McDonald (2007) and are also comparable to those calculated for the Merensky Reef by Godel et al. 
(2007) and slightly higher than those calculated by Naldrett et al. (2009) for the Merensky Reef. This shows that the initial magmatic sulfide present within the Platreef magma was already highly enriched in PGE, and during cooling and crystallization of the sulfide, the PGE tenor may have been diluted slightly by the addition of country rock sulfur from contamination processes (e.g. Sharman-Harris et al. 2005; Holwell et al. 2007). There is some variation between inclusions, however, in terms of bulk PGE composition, although PGE ratios are consistent, as shown by the chondrite-normalized patterns. The variation in precious metal tenor may be a factor of where each droplet was mobilized from. For example, higher tenors may be found closer to conduits in the deeper plumbing system (McDonald and Holwell 2007), although when mobilized, individual droplets from different parts of such a conduit system may have been entrained together.

This offers support to the notion that the Platreef sulfides attained their high PGE tenors prior to emplacement, for example in a staging chamber (Holwell et al. 2007; McDonald and Holwell 2007). Due to the fact that the Platreef was intruded as a sill, or series of sills, without a large volume of mafic magma residing above it (Holwell et al. 2005), the magma must have brought in entrained PGE-rich sulfides, with sulfide saturation and PGE enrichment taking place at an earlier, deeper stage. The presence of these highly PGE-enriched sulfide droplets within the earliest crystallising phase in the Platreef is entirely supportive of this theory. These observations are consistent with processes modelled by Kerr and Leitch (2005) and with the discovery of chalcophile-elementdepleted magmas associated with the pre-Platreef intrusions of the Lower Zone in the northern limb (McDonald et al. 2009). Kerr and Leitch (2005) modelled PGE tenors in sulfide systems involving interaction with multiple stages of magma, including cases where passage of subsequent magmas over pre-formed sulfides may dissolve some sulfide, but leave PGE within the remaining sulfide, thus producing very high PGE tenors in sulfides in such systems. Kerr and Leitch (2005) state that for a closed system (with $D_{P t}=10,000$ and $R=\sim 10^{6}$ ), only around $180 \mathrm{ppm}$ Pt can be generated in the sulfide. Our data show some droplets with concentrations several times this (Table 2), which is consistent with their multistage upgrading models, which in turn supports the model of Platreef enrichment in a staging chamber or conduit system (McDonald and Holwell 2007).

Average $\mathrm{Pt} / \mathrm{Pd}$ ratios are just above unity, which is slightly higher than average for the Platreef which are generally in the region of unity or below (McDonald et al. 2005; Kinnaird 2005; Holwell and McDonald 2006). This may be an artifact of the samples used in this study being of only a relatively limited provenance, and the authors are currently involved in a much broader study of these inclusions which will be reported elsewhere. If the compositions of the homogenized droplets are representative of the Platreef and northern limb in general, they also lend support to the arguments of McDonald et al. (2005) who used PGE geochemistry, and in particular $\mathrm{Pt} / \mathrm{Pd}$ ratios of close to unity to argue against a potential link between the Platreef in the northern limb of the Bushveld Complex and the Merensky Reef and Critical Zone of the rest of the Complex (e.g. Kruger 2005). The Merensky Reef has Pt/Pd ratios of around 2, and the modeling of Godel et al. (2007) and Naldrett et al. (2009) all give $\mathrm{Pt} / \mathrm{Pd}$ ratios of close to or just under 2 for modelled sulfide liquid parental to the Merensky Reef.

The only semi-metals detected in significant amounts in the homogenized droplets were $\mathrm{Bi}$ and $\mathrm{Te}$ and some minor As. Bismuth and Te typically form PGM with Pt and Pd, and in the more 'primary' Platreef mineralization in areas such as Overysel (Holwell and McDonald 2007), these are the most common PGM. Some arsenides (mainly sperrylite) are observed in all sections of the Platreef, and small amounts in the 'primary' assemblages are likely to be of magmatic origin. In more contaminated section such as Turfspruit, where a significant assimilation of shales (from the Duitschland formation) has taken place (Hutchinson and McDonald 2008), and in the footwall rocks at Sandsloot (Holwell et al. 2006), there is a higher percentage of As- and Sb-bearing PGM. The presence of abundant Asand Sb-bearing PGM has been suggested to be due to assimilation of these elements from the shale during contamination (Hutchinson and Kinnaird 2005, Hutchinson and McDonald 2008). At Sandsloot, hydrothermal redistribution into the footwall has formed As- and Sb-dominant assemblages in footwall calc-silicates (Holwell et al. 2006), and it is likely that these elements have been sourced from the floor rock sediments during fluid interaction at this locality. The Platreef at Overysel is intruded at a lower stratigraphic level, between basement gneisses and Malmani dolomites that do not contain elevated levels of As and $\mathrm{Sb}$, and the lack of these elements in the droplets analyzed here is entirely consistent with these concepts.

\section{Wider implications of the technique}

The technique of homogenizing sulfide inclusions has significant implications for a range of geological problems This pilot study has shown the potential for using this technique in determining initial metal concentrations and relative timing of precious metal enrichment within immiscible sulfide droplets at magmatic temperatures and the implications for the genesis of, in this case the Platreef, but in principle the technique is generally applicable to any magmatic sulfide system where sulfide liquid droplets are 
trapped by a host mineral. In addition to this, the technique has significant further applications, with the potential to determine $\mathrm{S}$ and $\mathrm{Os}$ isotope signatures of the droplets, with the sources of $\mathrm{S}$ and precious metals fundamentally important in generating genetic models for PGE-Ni-Cu sulfide deposits. This in turn has implications for developing exploration models for such deposits, with genetic models playing an integral part in exploration strategy. For example, using the conclusions put forward here for the Platreef, there are implications for further deposits within deeper chambers or conduit systems feeding the Platreef. Similarly, this technique could be applied to studies of other known conduit systems such as Voisey's Bay, Uitkomst or Noril'sk.

A further application could be for investigating sulfide inclusions in mantle rocks, including those in diamonds, a truly representative analysis of which is essential in being able to interpret mantle processes from such inclusions. The analysis of sulfide inclusions in diamonds, for example using Os isotopes, also has the same problem of ablating fractionated droplets, and the question therefore of whether a truly representative analysis is gained.

\section{Conclusions}

Trapped sulfide inclusions hosted by early crystallising phases in mafic intrusions, such as chromite, hold evidence for the nature of early sulfide liquids in terms of metal concentrations and ratios and isotope ratios. This information can be crucial in determining processes of ore formation such as the timing of sulfide saturation and metal enrichment in magmatic PGE-rich sulfide ores. The problem of preferential sampling encountered during cutting and polishing of fractionated droplets can be eliminated by homogenizing the sulfide by heating to a temperature of $1,195^{\circ} \mathrm{C}$ and quenching. The data presented here clearly show the benefits of using this approach. Application of this technique to droplets of sulfide trapped in chromite in the Platreef has shown evidence of an early, highly PGErich sulfide liquid, which supports genetic models for the formation of the Platreef involving pre-concentration of sulfide with PGE at an early, deep stage prior to intrusion. The method can be widely used to investigate ore genesis in magmatic sulfide deposits and also has the potential to be used in studies of mantle processes, e.g. sulfide inclusions in diamonds.

Acknowledgments The authors would like to thank the management of Anglo Platinum for facilitating access to core from Overysel, particularly Gordon Chunnet and Adrian Colloty. This work arose from David Holwell's PhD research, which was funded by the Natural Environment Research Council and supported by Anglo Platinum through Industrial CASE project (NER/S/C/2003/11952). Reviews by
Leonid Danyushevsky and an anonymous referee and editing by Chris Ballhaus are acknowledged in improving the quality of the manuscript.

\section{References}

Armitage PEB, McDonald I, Edwards SJ, Manby GM (2002) Platinum-group element mineralization in the Platreef and calc-silicate footwall at Sandsloot, Potgietersrus District South Africa. Appl Earth Sci (Trans Inst Min Metall B) 111:B36-B45

Ballhaus C, Sylvester PJ (2000) Noble metal enrichment processes in the Merensky Reef, Bushveld Complex. J Petrol 41:545-561

Ballhaus C, Tredoux M, Späth A (2001) Phase relations in the Fe-Ni$\mathrm{Cu}-\mathrm{PGE}-\mathrm{S}$ system at magmatic temperature and application to Massive Sulfide Ores of the Sudbury Igneous Complex. J Petrol 42:1911-1926

Barnes S-J, Makovicky E, Makovicky M, Rose Hansen J, Karup Moller S (1997) Partition coefficients for Ni, Cu, Pd, Pt, Rh and Ir between monosulfide solid solution and sulfide liquid and the formation of compositionally zoned $\mathrm{Ni}-\mathrm{Cu}$ sulfide bodies by fractional crystallization of a sulfide liquid. Can J Earth Sci 34:366-374

Barnes S-J, Cox RA, Zientek ML (2006) Platinum-group element, gold, silver and base metal distribution in compositionally zoned sulfide droplets from the Medvezky Creek Mine, Noril'sk, Russia. Contrib Mineral Petrol 152:187-200

Buchanan DL, Nolan J (1979) Solubility of S and sulfide immiscibility in synthetic thoeliitic melts and their relevance to the Bushveld Complex. Can Mineral 17:483-494

Cabri LJ, Laflamme JHG (1976) The mineralogy of the platinumgroup elements from some copper-nickel deposits of the Sudbury area, Ontario. Econ Geol 71:1159-1195

Cawthorn RG, Barton JM Jr, Viljoen MJ (1985) Interaction of floor rocks with the Platreef on Overysel, Potgietersrus, Northern Transvaal. Econ Geol 80:988-1006

Danyushevsky LV, Della Pasqua FN, Sokolov S (2000) Reequilibration of melt inclusions trapped by magnesian olivine phenocrysts from subduction-related magmas: petrological implications. Contrib Mineral Petrol 138:68-83

Danyushevsky LV, Ryan C, Kamenetsky V. Crawford A (2001) Inclusions of Sulphide Immiscible Melts in Primitive Olivine Phenocrysts from Mantle-Derived Magmas; Preliminary Results. Abstr. AGU Fall Meeting. Eos 82, No.47/suppl. F1285

Deines P, Nafziger RH, Ulmer GC, Woermann E (1974) Temperature - oxygen fugacity tables for selected gas mixtures in the system $\mathrm{C}-\mathrm{H}-\mathrm{O}$ at one atmosphere total pressure. Bulletin of the Earth And Mineral Sciences Experimental Station No88, College of Earth and Mineral Sciences. Pennsylvania State University, p 129

Eales HV, Cawthorn RG (1996) The Bushveld Complex. In: Cawthorn RG (ed) Layered Intrusions. Elsevier Science, pp 181-230

Fleet ME, Chryssoulis SL, Stone WE, Weisener CG (1993) Partitioning of platinum-group elements and $\mathrm{Au}$ in the $\mathrm{Fe}-\mathrm{Ni}$ $\mathrm{Cu}-\mathrm{S}$ system: experiments on the fractional crystallization of sulfide melt. Contrib Mineral Petrol 115:36-44

Godel B, Barnes S-J, Maier WD (2007) Platinum-group elements in sulfide minerals, platinum-group minerals, and whole-rocks of the Merensky Reef (Bushveld Complex South Africa): implications for the formation of the reef. J Petrol 48:1569-1604

Harris C, Chaumba JB (2001) Crustal contamination and fluid-rock interaction during the formation of the Platreef, Northern Limb of the Bushveld Complex South Africa. J Petrol 42:1321-1347

Helmy HM, Ballhaus C, Berndt J, Bockrath C, WohlgemuthUeberwasser C (2006) Formation of Pt, Pd and Ni tellurides: 
experiments in sulfide-telluride systems. Contrib Mineral Petrol 153:577-591

Holwell DA, McDonald I (2006) Petrology, geochemistry and the mechanisms determining the distribution of Platinum-Group Element and Base Metal Sulfide mineralization in the Platreef at Overysel, northern Bushveld Complex, South Africa. Miner Dep 41:575-598

Holwell DA, McDonald I (2007) Distribution of platinum-group elements in the Platreef at Overysel, northern Bushveld Complex: a combined PGM and LA-ICP-MS study. Contrib Mineral Petrol 154:171-190

Holwell DA, McDonald I (2010) A Review of the Behaviour of Platinum Group Elements within Natural Magmatic Sulfide Ore Systems. Plat Metals Rev 54:26-36

Holwell DA, Armitage PEB, McDonald I (2005) Observations on the relationship between the Platreef and its hangingwall. Appl Earth Sci (Trans Inst Min Metall B) 114:199-207

Holwell DA, McDonald I, Armitage PEB (2006) Platinum-group mineral assemblages in the Platreef at the South Central Pit, Sandsloot Mine, northern Bushveld Complex South Africa. Min Mag 70:83-101

Holwell DA, Boyce AJ, McDonald I (2007) Sulfur isotope variations within the Platreef: genetic implications for the origin of sulfide mineralization. Econ Geol 102:1091-1110

Hutchinson D, Kinnaird JA (2005) Complex multi-stage genesis for the $\mathrm{Ni}-\mathrm{Cu}$-PGE mineralisation in the southern region of the Platreef, Bushveld Complex South Africa. Appl Earth Sci (Trans Inst Min Metall B) 114:208-224

Hutchinson D, McDonald I (2008) Laser ablation ICP-MS study of platinum-group elements in sulfides from the Platreef at Turfspruit, northern limb of the Bushveld Complex, South Africa. Miner Dep 43:695-711

Jollie D (2009) Platinum 2009. Johnson Matthey, Royston, UK 56 pp

Kamenetsky V (1996) Methodology for the study of melt inclusions in Cr-spinel, and implications for parental melts of MORB from FAMOUS area. Earth and Planet Sci Letters 142:479-486

Kerr A, Leitch AM (2005) Self-destructive segregation systems and the formation of high-grade magmatic ore deposits. Econ Geol 100:311-332

Kinnaird JA (2005) Geochemical evidence of multiphase emplacement in the southern Platreef. Appl Earth Sci (Trans Inst Min Metall B) 114:B225-B242

Kinnaird JA, McDonald I (2005) An introduction to the mineralisation in the northern limb of the Bushveld Complex. Appl Earth Sci (Trans Inst Min Metall B) 114:B194-B198

Kinnaird JA, Hutchinson D, Schürmann L, Nex PAM, de Lange R (2005) Petrology and mineralization of the southern Platreef: northern limb of the Bushveld Complex South Africa. Miner Dep 40:576-597

Kruger FJ (2005) Filling the Bushveld Complex magma chamber: lateral expansion, floor interaction, magmatic unconformities and giant chromitite and PGE deposits. Miner Dep 40:451472

Li C, Naldrett AJ (1993) Sulfide capacity of magma: a quantitative model and its application to the formation of sulfide ores at Sudbury, Ontario. Econ Geol 88:1253-1260

Li C, Barnes S-J, Makovicky E, Rose-Hansen J, Makovicky M (1996) Partitioning of nickel, copper, iridium, rhenium, platinum and palladium between monosulfide solid solution and sulfide liquid: effects of composition and temperature. Geochim Cosmochim Acta 60:1231-1238

Li C, Ripley EM, Maier WD, Gomwe TES (2002) Olivine and S isotopic compositions of the Uitkomst $\mathrm{Ni}-\mathrm{Cu}$ sulfide ore-bearing complex South Africa: evidence for $\mathrm{S}$ contamination and multiple magma emplacements. Chem Geol 188:149-159
Maier WD (2005) Platinum-group element (PGE) deposits and occurrences: Mineralization styles, genetic concepts, and exploration criteria. J Afr Earth Sci 41:165-191

Manyeruke TD, Maier WD, Barnes S-J (2005) Major and trace element geochemistry of the Platreef on the farm Townlands northern Bushveld Complex. S Afr J Geology 108:381-396

McDonald I (2005) Development of sulfide standards for the in situ analysis of platinum-group elements by laser ablation inductively coupled plasma-mass spectrometry (LA-ICP-MS). In: Törmänen TO, Alapieti TT (eds) $10^{\text {th }}$ International Platinum Symposium, Ext Abstracts, pp 468-471

McDonald I, Holwell DA (2007) Did lower zone magma conduits store PGE-rich sulfides that were later supplied to the Platreef? S Afr J Geol 110:611-616

McDonald I, Ohnenstetter D, Ohnenstetter M, Vaughan DJ (1999) Palladium oxides in ultramafic complexes near Lavatrafo, Western Andriamena Madagascar. Min Mag 63:345-352

McDonald I, Holwell DA, Armitage PEB (2005) Geochemistry and Mineralogy of the Platreef and "Critical Zone" of the Northern Lobe of the Bushveld Complex, South Africa: Implications for Bushveld Stratigraphy and the Development of PGE Mineralization. Miner Dep 40:526-549

McDonald I, Holwell DA, Wesley B (2009) Assessing the Potential Involvement of an Early Magma Staging Chamber in the Generation of the Platreef Ni-Cu-PGE Deposit in the Northern Limb of the Bushveld Complex: A Pilot Study of the Lower Zone Complex at Zwartfontein. Appl Earth Sci (Trans Inst Min Metall B) 118:5-20

McNeill AW, Danyushevsky LV, Kamenetsky V, Feig S, Crawford AJ (2008) Inclusions of immiscible sulfide melts in olivine phenocrysts from mantle-derived magmas. Geochim Cosmochim Acta 72:A616

Mungall JE, Andrews DRA, Cabri LJ, Sylvester PJ, Tubrett M (2005) Partitioning of $\mathrm{Cu}, \mathrm{Ni}, \mathrm{Au}$, and platinum-group elements between monosulfide solid solution and sulfide melt under oxygen and sulfur fugacities. Geochim Cosmochim Acta 69: $4349-4360$

Naldrett AJ (2004) Magmatic Sulfide Deposits. Geology, Geochemistry and Exploration. Springer, Berlin

Naldrett AJ, Lehmann J (1987) Spinel non-stoichiometry as the explanation for $\mathrm{Ni}$-, $\mathrm{Cu}$ - and PGE-enriched sulfides in chromitites. In: Prichard HM, Potts PJ, Bowles JWF, Cribb SJ (eds) Geo-Platinum '87. Elsevier, London, UK, pp 113-143

Naldrett AJ, Wilson A, Kinnaird JA, Chunnett G (2009) PGE Tenor and Metal Ratios within and below the Merensky Reef, Bushveld Complex: Implications for its Genesis. J Petrol 50:625-659

Ohmoto H, Rye RO (1979) Isotopes of sulfur and carbon. In: Barnes HL (ed) Geochemistry of Hydrothermal Ore Deposits, 2nd edn. Wiley and Sons, London, pp 509-567

Ohnenstetter M, Johan Z, Cocherie A, Fouillac AM, Guerrot C, Ohnenstetter D, Chaudisson M, Rouer O, Makovicky E, Mackovicky M, Rose-Hansen J, Karup-Moller S, Vaughan DJ, Turner G, Pattrick RAD, Gize AP, Lyon IC, McDonald I (1999) New exploration methods for platinum and rhodium deposits poor in base-metal sulfides-NEXTPRIM. Appl Earth Sci (Trans Inst Min Metall B) 108:B119-B150

Prichard HM, Hutchinson D, Fisher PC (2004) Petrology and crystallization history of multiphase sulfide droplets in a mafic dike from Uruguay: implications for the origin of $\mathrm{Cu}-\mathrm{Ni}$-PGE sulfide deposits. Econ Geol 99:365-376

Ripley E, Li C (2003) S isotope exchange and metal enrichment in the formation of magmatic $\mathrm{Cu}-\mathrm{Ni}-(\mathrm{PGE})$ deposits. Econ Geol 98:636-641

Ripley EM, Lightfoot PC, Li C, Elswick ER (2003) S isotopic studies of continental flood basalts in the Noril'sk region: Implications 
for the association between lavas and ore-bearing intrusions. Geochim Cosmochim Acta 67:2805-2817

Roeder PL, Reynolds I (1991) Crystallization of chromite and chromium solubility in basaltic melts. J Petrol 32:909-934

Sharman-Harris E, Kinnaird JA, Harris C, Horstmann UE, Wing B (2005) A new look at sulfide mineralization of the northern limb, Bushveld Complex: a stable isotope study. Appl Earth Sci (Trans Inst Min Metall B) 114:252-263

Spandler C, Eggins SM, Arculus RJ, Mavrogenes JA (2000) Using melt inclusions to determine parent-magma compositions of layered intrusions: Application to the Greenhills Complex (New Zealand), a platinum group minerals-bearing, island-arc intrusion. Geology 28:991-994

Spandler C, Mavrogenes JA, Arculus RJ (2005) The origin of chromitites in layered intrusions: Evidence from chromite-hosted melt inclusions from the Stillwater Complex. Geology 33:893-896
Spandler C, HStC O’Neill, Kamenetsky VS (2007) Survival times of anomalous melt inclusions from element diffusion in olivine and chromite. Nature 447:303-306

Sparks HA, Mavrogenes JA (2005) Sulfide partial melting at Broken Hill, Australia. Econ Geol 100:773-779

Sylvester PJ, Cabri LJ, Tubrett MN, McMahon G, Laflamme JHG, Peregoedova A (2005) Synthesis and evaluation of a fused pyrrhotite standard reference material for platinum-group element and gold analysis by laser ablation-ICPMS. In: Tormanen TO, Alapieti TT (eds) 10th International Pt Symposium, Extended Abstract. Geological Survey of Finland, Espoo, Finland, pp 16-20

Yudovskaya MA, Kinnaird JA (2010) Chromite in the Platreef (Bushveld Complex, South Africa): occurrence and evolution of its chemical composition. Miner Dep 45:39-369 